\title{
The Rise and Limits of Education Policy. Gendered Education
}

\author{
Ansgar Weymann \\ University of Bremen
}

\begin{abstract}
Education policy is a core element of the modern state's sovereignty and autonomy. Education serves the state as a means of integrating society through culture and ideology, furthermore as a key tool for improving political power and legitimacy, and finally fueling and stimulating economic growth via human capital investment. Eighteenth century state-building brought the expansion and improvement of educational institutions, and the nineteenth century the development of the fully-fledged education-state. In the twentieth "human capital" century, education policy reached its pinnacle, characterized by unprecedented growth in terms of educational attainment, investments and returns. However, in the last decades, weaknesses of education policy have become visible: the declining growth of human capital returns, problems of reducing social inequality as well as deficient cultural and social integration. Throughout centuries the schooling of girls followed the schooling of boys with delay. Yet, today girl's gross tertiary school enrollment is globally ahead of boys. Indeed, progress of education is a process of longue durée.
\end{abstract}

Key words: Education policy, history of education, recent limits and challenges, globalization and the national education prerogative

\section{L'expansion et les limites de la politique de l'éducation. Education genre}

Résumé: La politique d'enseignement marque essentiellement la souveraineté et l'autonomie de l'état moderne, pour qui l'éducation joue le rôle d'intégration sociale par l'intermédiaire culturel et idéologique. En outre, elle représente le levier substantiel pour améliorer la puissance et la légitimité politiques, et, en fin de compte, elle stimule la croissance économique en réalisant des investissements dans les ressources humaines. Le dix-huitième siècle engendre l'expansion et l'amélioration lentes des bases du système éducatif et le dix-neuvième siècle se caractérise par le développement de l'état éducatif intégral. C'est le vingtième siècle qui marque le zénith de l'essor des ressources humaines, caractérisé par une croissance de diplômes, des investissements et des rendements sans précédent. Cependant, durant les dernières décades, on peut observer des faiblesses structurelles dans le domaine politique portant sur le domaine éducatif, à savoir: baisse nette du rendement des ressources humaines, problèmes de la réduction de disparités sociales ainsi que le constat de la déconfiture de l'intégration culturelle et sociale. Depuis des siècles on peut constater que la formation éducative des filles marque un retard par rapport à celle des garçons. Or, de nos jours, le taux de jeunes filles immatriculées dans les institutions chargées d`études supérieures est globalement en train de dépasser celui des garçons. Par conséquent, l'évolution dans le monde de l'enseignement est une procédure de 
longue durée.

Mots-clés: Politique éducative, histoire de l'éducation, recent limites et défis, mondialisation et la prérogative nationale

\section{La expansión y los límites de la política educativa. Educación de género}

Resumen: La política educativa es un elemento central de la soberanía y la autonomía del Estado moderno. La educación sirve al Estado para integrar a la sociedad a través de la cultura y la ideología. Además, es una herramienta clave para fortalecer el poder y la legitimidad política. Finalmente, alimenta y estimula el crecimiento económico a través de la inversión de capital humano. La construcción del Estado en el siglo dieciocho trajo una expansión y mejora de las instituciones educativas, desembocando en el desarrollo del Estado educativo durante el siglo diecinueve. En el siglo veinte del "capital humano", la política educativa ha alcanzado su cima, caracterizada por un crecimiento sin precedentes en términos de logros educativos, inversiones y ganancias. En las últimas décadas, no obstante, las debilidades de ese desarrollo histórico de la política educativa son cada vez mas obvias: cae el crecimiento de los retornos del capital humano, aumentan los problemas para reducir la desigualdad social y para fortalecer la integración cultural y social etc. A lo largo de los siglos, la escolarización de las chicas sufrió un importante retraso en comparación con la escolarización de los chicos. Hoy, sin embargo, la inscripción bruta en educación terciaria de las chicas, globalmente, está por delante de los chicos. Resulta, efectivamente, que el progreso de la educación es un proceso de longue durée.

Palabras clave: Política educativa, historia de la educación, límites y desafíos recientes, globalización y la prerrogativa nacional

\section{Introduction $^{1}$}

The sovereignty and autonomy of the modern state owes much to its education policy. Indeed, as education has been a core element of the political, economic and cultural development of modern societies, it has thus become a 'politicum', or a central political issue, which requires explanation (section 1). The rise of education policy began in the sixteenth century and comprises major transitions, beginning with the early diffusion of founding ideas during the Renaissance, Reformation, and Enlightenment periods. Eighteenth century state building brought the expansion and improvement of educational institutions, and the nineteenth century the development of the fully-fledged national education-state in Europe (section 2). In the twentieth, 'human capital' century, the education state reached its pinnacle, characterized by unprecedented growth in terms of educational attainment, investments and returns. For a long time, schooling and higher education of girls followed the schooling of boys with delay. Yet, today girls' gross tertiary school enrollment is globally ahead of boys (section 3). However, in the last decades, serious limits to the potential of education policy became visible: the declining growth of human capital returns, the persistence of social inequality as well as deficient cultural and social integration (section 4.1). This development was accompanied by a waning interest of 
leading American, British, French and German newspapers in education and education policy (section 4.2).

In this study, it is argued that the reason for this transformation is the convergence of the prices of goods, labor, capital, and human capital. Educational certificates are no exception. Global markets continually evaluate education credentials and ascribe them with ranking positions which make professional skills and competences of their holders internationally comparable. That way, they subjugate previously protected national credentials to world market conditions and demands, thereby challenging the hitherto national prerogative of education (section 5). "The isomorphic processes that now frame education policy are often constituted globally and beyond the nation-state, even if they are still articulated in nationally specific terms" (Rizvi \& Lingard, 2010, p.3). In particular, the transition from western to non-western globalization has gained momentum, strengthening the antagonism between the free flow of human capital and the national education-state, which is seen as a defensive mechanism against presumed and real threats by globalization (section 6).

\section{The Political Economy of Education Policy}

\section{Political Power: Meritocracy and Loyalty}

First of all, education is a valuable source of political power; a well-esteemed instrument to achieve loyalty within mass societies (Mann, 1986). Over the course of centuries, education gradually became a means of the meritocratic distribution of life chances of individuals and groups: In other words, it became an uncontested precondition for entry into the clergy, city and state administration, guilds, and into the expanding professions like medicine, law and engineering and skilled industrial jobs. This rising and increasingly educated middle class successfully conquered all ranks and spheres of private and public employment, with educational degrees as tools for meritocratic claims in their hands. That, in turn, made educational degrees attractive for newly ascending social strata. Progressive general education breached the principles of inheritance of legal and material status, of positions and class barriers, and replaced ascribed status of population groups more and more by the principle of achieved educational meritocracy. Today, meritocracy through credentials is widely accepted as a legitimate basis for the distribution of goods and commodities throughout the population. As a consequence, the ongoing fight for valuable educational credentials mirrors the fight for social positions and reflects the balance of power in society.

\section{Economic Growth: The Alliance of State and Human Capital}

Furthermore, education is a key source of private and public economic growth. The dissemination of work ethics and disciplined everyday behavior through general education of the population became crucially important policy goals in modern societies. Mandatory education was introduced in order to transform agrarian and urban underclass habits into working and middle-class skills necessary for trade, commerce and industry. Today, the legitimacy of spending on education is increasingly based on public trust in the returns of educational investments. This application of economic criteria to education has gained preponderance at the expense of religious education, and humanist considerations about education as personal development. The rationale behind this is the relationship between cognitive skills (as measured by international 
student assessment) and national economic growth (Hanushek \& Woessmann, 2015; Woessmann \& Peterson, 2007). The knowledge-based economies of developing and developed countries need a high level of public and private investment in lifelong learning, the continuous mobilization of scarce human resources, and the control of the quality, efficiency and effectiveness of education. Education policy distinguishes modern from traditional societies, the latter of which did not systematically invest in human beings (Schultz, 1981).

In short: From an economic perspective, education policy is driven by the options and sanctions of markets and capitalism as the modern state is fully dependent on the levying of taxes and fees from a prosperous civil society. For this reason investment in human capital turned into a central element of state policy. Individual economizing on human capital also became normal.

\section{Cultural Integration: Socialization and Homogenization}

Finally, education policy played and still plays a crucial role in state-building. Education is regarded as one of the best means for constructing a loyal democratic public and citizenry through generating a sufficient minimum of cultural homogeneity by which to integrate society. Centuries of modernization, urbanization and industrialization transformed the rural population, often still organized in extended families, clans, tribes, and religious communities, into an alienated and fragmented urban proletariat. This process was and still is accompanied by internal and international migration, which is stimulating conflicts between old residents and newcomers, rich and poor, classes, ethnicities and religions. These transformation processes always bear a threat to the integration of state and society. Yet, in order to achieve a community of loyal citizens standardized national education schemes and in particular education for the sake of nationalism is perceived as a useful strategy, since national identity rises above the level of the old communities of family and religion.

However, this education of unity within the state is more difficult to realize among the lower classes than within the middle classes, the latter seeing themselves mostly as the carriers and beneficiaries of the nation-state and social advancement, whereas the lower classes must break with primordial familial, ethnic and religious traditions. Historically the pride in education only slowly and gradually expanded from the upper to the lower classes. From the perspective of cultural integration, education policy is the appropriate means to homogeneously shape large populations. In particular, elementary schools and preschools are praised as useful institutions to forge a minimum of cultural homogeneity in the face of economic and political transformations, mass migration and globalization.

\section{The Rise of Education Policy in History}

\section{The Medieval: Christian, Imperial, Urban Institutions and the Reformation}

The rise of education policy is closely linked to the history of European states and societies. Schools and universities increasingly divided "the population into the educated elite and the unschooled or less-schooled mass" (Grendler, 2001, p.329). Education creates social distinction because it enables people to in principle accomplish individual achievements in professional occupations and the civil service independently of status ascription by heritage, class, ethnicity, religion or gender. Throughout half a millennium, education has included ever larger shares of the population for ever longer periods of their lives in schooling. 
With the fall of the Roman Empire, non-religious education almost ceased to exist in Europe. Christianity became the new force of cultural and institutional isomorphism. Education turned into primarily religious education, mainly offered by the church. Only rarely were antique traditions of education resumed. For example, Charlemagne re-established a non-religious sector of education at his 'School of the Palace.' In letters to Bishop Lullus of Mainz und Abbot Bangulf of Fulda in the year 787, he asked for them to offer elementary education for the common people at the parish level, as well as higher studies at their regional capitals for sons of high standing (Durkheim, 1938).

The medieval schools were parish schools, schools of religious orders, private schools, boarding schools, and city schools. Mostly, city schools were Latin schools for the children of those of higher standing in the city society. Schooling of the lower classes occasionally comprised petty or vernacular schools, often called 'Winkelschulen' in German, but there was no comprehensive public schooling for the mass of children from lower social standings (Neugebauer, 2005). Schools were maintained primarily by the collection of school fees, although they were also sometimes supported by public-tax money from the urban community. The rate of literacy of the population was low and almost exclusively a privilege of male students from higher classes, for example from the aristocrats, patricians, and the citizenry like merchants, legal and medical professions (Lawson \& Silver, 1973).

By the fifteenth century, municipalities in Germany of one thousand inhabitants or more had established Latin schools for children of higher social standing. A coexistence of Christian and urban schools emerged. Jakob Wimpfeling (1501), a Humanist and professor at Heidelberg University, as well as a resident and citizen of the (at that time, German) city of Strasbourg, vigorously argued in favor of the urban Latin school maintained by the city and responsible for the education of the offspring of citizens, patricians and nobles. However, the urban Gymnasium, he cautiously claimed, should not operate at the expense of the older cathedral and monastery schools.

The Reformation turned education into a public and normative good of statehood. "Luther ... argued for universal compulsory education" and "protestant school orders firmly placed the state (prince or city council) in charge of the schools" (Grendler, 2001, p.333). This general political claim intended to install a publicly maintained Protestant school and university system. The transition from elementary school to high school and to university education was to be regulated more selectively than had hitherto been the case, and the admission processes ought to be more strictly supervised by city or state authorities (Luther, 1520). Melanchthon (1543), a Humanist and Rector of the University of Wittenberg, carrying forward Luther's demands on education policy, argued strictly in favor of the rule of law in the field of education, established by the city legislation and counsel. However, the implementation of the Protestant ideas of education policy was imperfect even in Protestant states and cities. In the Catholic countries of Europe, Catholic orders - especially the order of the Societas Jesu - also made a significant impact on schooling.

Girls were typically taught less than boys. In his letter, "An die Ratsherren aller Städte deutschen Landes" (To the councilors of all German cities), Luther (1524) asks the councilors to establish and enduringly maintain schools for boys and girls alike. His intention is the provision of a public Christian and humanist education for all children of all social standings, not at least their training to read the bible. Wittenberg opened its girls' school in 1530. Also, a number of 
women's orders, for example the order of the Ursuline sisters and the order of the Congregatio Jesu (founded in 1609) engaged in girls' education. They established their own educational institutions to instruct girls in reading, writing and handiwork.

Similar to schools, the medieval European university often developed out of wellesteemed monasteries or bishop schools. Universities were founded by papal bulls or imperial privilege. They served the demand of the clergy and the demand of a small secular clientele for the professions of law, medicine, and the civil service. In Germany, the Imperial Privilege of 1158 ('authentica habita') guaranteed protection of the university's autonomy, primarily against local forces. Within the boundaries of the "Holy Roman Empire of the German Nation" the first university privileged ${ }^{2}$ by the Emperor was Bologna in 1236, followed by Prague (1346), Vienna (1365), Heidelberg (1386) and Cologne (1389). Before the reformation, eighteen universities were founded and privileged. Enrollment was confined to men; women were not admitted to study at universities.

\section{State-Building and the Enlightenment}

The first effective steps towards a countrywide education policy across Europe were not taken before the formation of centralized states in the sixteenth to eighteenth centuries. In the beginning, this period was plagued by long lasting religious wars, civil conflicts and clashes in England, France, Germany and elsewhere. Education was used to integrate the multi-centered and multi-cultural populations by literacy, religious lectures (often according to the rule: cuius regio, eius religio ${ }^{3}$ ), teaching basic arithmetic, and a common language and historical narrative.

The ideas of the upcoming European Enlightenment (circa 1650 to 1800) saw education as a universal public and normative good, transcending the old boundaries of Christendom, clerical and feudal authorities, and self-governing cities. A fascinating piece of evidence of the early Enlightenment's education ideals was the proposal of a new German Constitution in 1656 in the aftermath of the destructive Thirty Years War (1618-1648). The proposed constitution declared that elementary schools should be available everywhere and be entered at the age of five. High schools should encourage parents and children, especially those of lower-class descent, to enroll and stay there as long as possible. At the university level, the number of graduates should be significantly increased to serve the rising demand for academics in modern society. Stipends and scholarships, funded by state tax revenues, should be available to cover the expenditures of students in financial need. In addition, students are encouraged to study abroad. Degrees were to be recognized across Europe (Seckendorff $(1656 ; 1995){ }^{4}$

These issues and the aims of the proposed constitution of 1656 sound familiar, because the basic ideas of human capital investment, credential meritocracy, and cultural integration by means of education are still the same after four hundred years. With the enlightenment, education turned into a panacea to improve state and society through the amelioration of peoples' minds and characters. Many texts from the enlightenment engage with the interconnection between education, state and citizens, such as Locke's (1690) Two Treatises of Government, and his Some Thoughts Concerning Education (1693), Hume's (1739) Treatise of Human Nature, Rousseau's (1762a) Émile and The Social Contract (1762b), Herder's (1774) Another Philosophy of History for the Education of Mankind, Fichte's (1800) political essay on The Closed Mercantilist State, and Kant's (1795) Project for a Perpetual Peace. However, no state prerogative within the realms of upbringing and education is recommended. 
Yet, the new goals of education policy could only be achieved through education of the working masses. Adam Smith's (1776) Wealth of Nations, Volume V, is dedicated to the balance of public versus private goods in the policy fields of education, military, judiciary, and infrastructure. His argument focuses on the externalized costs of the accelerating, capital-driven economy that creates a new wealth of nations - but not for all. It is here that education policy steps in. Whereas the gentleman pays his own costs of education, the state must take under its care the deracinated agrarian population, which has been transformed into a new industrial under-class populace, by implementing free schooling, work training, and public access to culture through state-financed and state-regulated measures.

In Prussia, the General School Order (Allgemeine Schulordnung, 1717) and the Prussian General School Regulations (Preußische Generalschulreglement, 1763) restricted the autonomy of communes and cities over their schools. They defined Normal Schools (Normalschulen), and Main Schools (Hauptschulen), as the standard types of schools. The hierarchy was composed of (often illegal) Winkelschulen, licensed private schools and public schools. In 1780, school commissions were established. Teachers needed to have an acquired certificate of proficiency (Zeugnis der Tüchtigkeit) and an approval of the locally responsible school commission, to become employed. Small state salaries were introduced. This development ended about 1800 with minister Massow's school and education reforms.

The eighteenth century brought considerable progress in the education of girls. It was common that weekly journals in England and Germany demanded equivalent education for both genders. At the end of the century, girls' schools existed in most cities. As a rule, their educational aims were bound to the social status of their students. So called educational institutes (Erziehungsinstitute) brought up very educated and well behaved "madams" of noble or bourgeois upper class origin; girls' schools (Mädchenschulen) took care of the middle class; and industrial schools (Industrieschulen) taught lower class' children how to cope with a hard-working life. Although students of industrial schools could be male or female, most pupils were girls. In Hamburg, in 1783, the share of girls among all students of industrial schools was 73 to 80 percent (Mayer, 2005, p. 204).

\section{Nation-States, Industrialization and the Growth of Educational Attainment}

The next step in the development of education policy was achieved with the formation of the nation-state in the nineteenth century. The nation-state subordinated religion, ethnicity, class, gender and the family as primordial and perennial institutions of community to its new rules of law, economy and governance. The nation-state was regarded as a stronghold of civilization, progress, safety, and protection and as a key instrument of rational economic organization and democratic political decision-making. The state became a prime tool of the rising political, juridical, professional, economic, scientific, and technical bourgeois elites, and the most important social construction of community. More consistently and intensively than before, education was used as a promising instrument to improve the industrialism, professionalism, and human capital of citizens and common people. The core idea was that the growth of capital and human capital investments can be transformed into a rise in a state's economic, political, military, and ideological power (Hall and Schroeder, 2006; Mann, 1986). Consequently, investment in human capital became crucial for the progress of states in Europe. The policy of introducing 
compulsory primary education and extended secondary education accompanied and facilitated the transition from agriculture and mining to industry.

This transformation of policy ideals is perfectly reflected by August Comte. Comte (1798 -1857) argues that in modern society progress is the foundation of social order. Progress is made through an understanding of the laws of reasoning, education, scientific advancements and the reorganizing of society. For Comte, all societal defects - the money economy, the rule of capital, crime, inequality, the crisis of marriage and the family, materialism, the decline of government, conflicts between sovereign European nations - will lead either to catastrophe or be resolved by the 'physique sociale', the new discipline of sociology. Only the state, through its role in upbringing and education, can remedy the permanent threat of societal disintegration and disaster (Comte 1853; 2009). As a result of the industrial revolution, however, Malthus (1798; 2007) expected a demographic and social disaster. He argued that, triggered by the amelioration of life conditions, the industrial revolution would subsequently generate a vicious cycle of population growth, ensuing starvation and the exhaustion of resources. This would become the inevitable fate of humanity. However, Malthus was not right. The course of history proved that he overestimated the traditional production factors of soil and natural resources, and underestimated the growing importance of science and human capital as the new production factors.

In Germany-Prussia, mandatory elementary schooling had been introduced in a number of acts as early as 1717,1721 , and 1726 . As a matter of fact, the origins of public schooling reach back long before the sixteenth century, and the time of introduction of compulsory education varied among the German Länder (Hammerstein \& Herrmann, 2005). ${ }^{5}$ In 1794 finally, Prussian common law (Allgemeines Preußisches Landrecht) stipulated: "Schools and universities are institutions maintained by the state. Their purpose is to teach useful knowledge and the sciences." (Herrmann, 2005, p. 547). ${ }^{6}$ These legal regulations did not result in the banning of private schools and home tuition. Furthermore, it took more than 100 years (from the first half of the eighteenth century to the middle of the nineteenth century) to fully instate the norm of mandatory education for all. For decades, school avoidance and truancy were widespread. However, in the year 1822 as many as 447 public secondary schools ${ }^{7}$ for boys existed in Prussia comprising 71,942 male students, compared to 263 public secondary schools for girls comprising 34,194 female students. In 1849 the number of public secondary schools for boys had risen to 505 enclosing 99,015 male students compared to 365 public secondary schools for girls comprising 53,570 female students (Zymek \& Neghabian, 2005; For comparisons with other countries see table 1).

At the beginning of the nineteenth century, secondary schools' curricula for boys and girls still differed considerably. Later, the curricula converged in terms of goals, content and exams. They became identical in the second half of the century. At that time the curriculum comprised the following school subjects for both genders: Religion, German, French, History, Mathematics, Geography, Sciences, Arts, Penmanship, Music, Handworks. Because the prime aim of the Prussian education policy was to teach boys for the civil service and professional occupations, the curriculum of secondary schools for boys at first was more standardized than the curriculum of girls' schools. In the second half of the nineteenth century however, curricula became equally standardized for both genders (Küpper 1987; Also, Bellaigue (2007) for comparisons of girls' education in France and Britain). The educational reforms intended to discipline and assimilate 
the populace and to maintain political and social order. This happened in response to the rapid population growth, accelerating economic transformations and political revolts (including the dramatic reshaping of state territories) that took place in Western and Central Europe at the end of the eighteenth and in the early nineteenth century.

In France, the Guizot Law (1833) did not make school attendance mandatory, yet the increased supply of schools led to a steady growth of student enrollment. The number of schools available grew fivefold throughout the nineteenth century from 0.3 to 1.5 schools per 100 pupils (Grew \& Harrigan, 1991). As a result, school attendance during the year, especially during the summer, became steadier. The schooling of girls closely followed the expanding schooling of boys (Grew \& Harrigan, 1991, p.125). Furthermore, enrollment in a lycée, the Latin school, was made conditional upon having successfully graduated from a preparatory or elementary school. In turn, graduation from the lycée with the Baccalauréat made it possible to enroll at a university (Chartier \& Compère, 1976).

In Prussia and France, school finances and buildings were improved and more effective school inspections were established to oversee the curricula and quality of teaching. In particular, the transformation of teaching from a part-time profession without higher educational prerequisites, to a full-time and skilled profession was directly connected to the establishment of state-sponsored mass education. The duty of teachers to serve as communal secretary or assistant to the curie, or both, disappeared gradually as this process advanced.

Prussia, France, and England (Seregny, 2001, p. 365) introduced professional training schemes for teachers that provided new opportunities not only for men but also for women from the lower-middle classes enabling them to climb the ladder of social hierarchy. More and more women were attracted to the teaching profession, turning primary education in particular into a female domain. "In 1837, two of every three school teachers were men; by 1863, more than half of all these elementary teachers were women. The total number of woman elementary school teacher in 1837 increased to more than four times at number in 1906" (Grew \& Harrigan, 1991, p. (215). "It is striking how readily teaching came to be an attractive career for women" (Grew \& Harrigan, 1991, p. 235). ${ }^{8}$

At the beginning of the twentieth century, educational attainment reached its first heyday all over Western Europe. The nation-state benefited large national economies and central administrations. Also, society became increasingly based on universal rights of citizenship, inclusive mass media communication and on the inclusion of the lower classes in primary and secondary education. Education was seen as a social right of the constitutional state, a foundation of democratic self-determination and as a means of providing wealth and security. By 1900, the most developed Western European States had accomplished a level of more than ninety percent of school enrollment of boys (Table 1).

\begin{tabular}{|lllll|}
\hline Country & 1820 & 1850 & 1870 & 1900 \\
\hline Germany-Prussia & 59 & 81 & 93 & 97 \\
Germany-Bavaria & & 83 & 84 & 94 \\
France & 60 & 88 & 94 \\
England and Wales & 66 & 88 & 90 \\
\hline
\end{tabular}




\begin{tabular}{|c|c|c|c|}
\hline Sweden & 59 & & 90 \\
\hline Austria & & 57 & 97 \\
\hline Italy & & 34 & 57 \\
\hline Russia & & & 29 \\
\hline
\end{tabular}

Table 1 Percent of male children aged 6 to 14 enrolled in schools in Europe 1820 - 1900 (Sources: Grendler 2001; Maynes 1985, p.134)

\section{Human Capital Century and the expansion of Higher Education}

We may call the twentieth century the century of the human capital. The progressive expansion of secondary and higher education that includes ever higher shares of the population is striking. The traditional European Latin School and the European University turned into a less selective and principally open secondary and tertiary system of education. Moreover, higher education became highly differentiated and interacting with the forces of markets and professions as well as with political and social movements. The provision of a more egalitarian, open system of higher education resulted in the unparalleled educational attainment of the population, and in a large supply of a highly skilled workforce.

Looking back, one can observe three great transformations in the history of higher education. The first transformation turned the mediaeval Christian university into the modern, secular university. The second transformation is known as the emergence of the research university in the nineteenth century. The development of the modern research university was closely interrelated with the rise of the modern nation-state and the establishment of an industrial economy and technology in Western nations (Rothblatt \& Wittrock, 1993, p.305). The third transformation opened general access for all strata of the population to higher education institutions. This last transformation has been taking place since the beginning of the twentieth century, and is further accelerating worldwide. The third, twentieth century university transformation (see table 2 for international and figure 2 for U.S. data) followed the nineteenth century school expansion (table 1 and figure 1) (Trow, 2010; Baker 2014 ${ }^{9}$ ).

Gains from investments in human capital, education, skills and competences, and in physical and mental health increased, whereas returns from ground rent and privileges as well as from the exploitation of soil, mining, and other natural resources decreased. Marginal utility from human capital investments went up, while marginal costs came down. The most important effect of the new political economy of education was that education proved to be profitable for everybody. Consequentially, the increase in the value of human capital provided incentives for ever more young people, women, lower classes, and other hitherto marginal or excluded sections of society to invest in education. The aggregated value of human capital grew thirteen times in the twentieth century, and the real income per hour quadrupled and quintupled in the United States, France, Germany, Sweden, and the United Kingdom (Schultz, 1981). In fact, the size and productivity of a highly-qualified workforce expanded in the developed countries, regardless of major working time reductions.

In the twentieth century, education policy was increasingly in favour of extending school education to the age of 18 and of opening the doors to higher education widely. Table 2 shows the rise of higher education attendance throughout the century. In 1910 the higher education 
participation rate per cohort was about 1 to 2 percent. In contrast, this rate achieved more than 40 percent in 1995. This development was driven by permanent technological innovations, the call for ever more workforce flexibility and new skills, and was pushed by more egalitarian norms and a growing sensitivity with respect to inequality. Also important was the increasingly public provision and funding of education.

Throughout this human capital century, the United States led the way. Here, the expansion of high schools and higher education began much earlier and developed far more rapidly compared to European nations. The rise of high school attendance, the increase of college enrollment, and the growing number of graduate schools were based on this historically early widening of high school access and on the open system of higher education.

\begin{tabular}{|llllllll|}
\hline Country & 1910 & 1950 & 1960 & 1970 & 1980 & 1990 & 1995 \\
Albania & & & 5 & 8 & 8 & 10 & 10 \\
Switzerland & 2 & 4 & 6 & 8 & 18 & 26 & 33 \\
Germany (FRG) & 1 & 4 & 6 & 14 & 26 & 34 & 44 \\
Spain & 1 & 2 & 4 & 9 & 23 & 37 & 49 \\
Great Britain & 1 & 3 & 9 & 14 & 19 & 30 & 50 \\
France & 1 & 4 & 7 & 16 & 25 & 40 & 51 \\
Finland & 1 & 4 & 7 & 13 & 32 & 49 & 70 \\
Europe & 1 & 4 & $\mathbf{8}$ & 14 & 22 & 30 & 42 \\
Var. C. Europe & 65 & 34 & 31 & 26 & 27 & 33 & 30 \\
Turkey & & & 3 & 6 & 5 & 13 & 18 \\
USA & 3 & 17 & 21 & 31 & 56 & 75 & 81 \\
\hline
\end{tabular}

Table 2 Higher Education Attendance 1910 to 1995. Number of Students Compared to the Number of 20-24-year-olds (Source: Kaelble 2007, p. 392)

Since 1876, more years of schooling were completed by each subsequent birth cohort of the US native population (Figure 1). Until the end of the twentieth century, the years of schooling completed per birth cohort increased from less than eight to fourteen years (Goldin \& Katz, 2008, p.21). In the nineteenth century, and then again in the 1960 s, girls were more successful than boys. Within the same period, college graduation rate rose as well - from less than 5 to over 30 percent (Goldin \& Katz, 2008, p.249). Here again, since the 1960s, female students achieved a higher college-graduation rate than boys (Figure 2 ).

Colleges and universities, ranging from community colleges to Ivy League universities, became institutions of educational achievement for the entire population. For example, the number of higher education students grew from 157,000 in 1890 to 600,000 in 1920, and to 2.7 million in 1950 (Busemeyer, 2006, p.174). In 1960, as many as forty percent of secondary school graduates enrolled at some institution of higher education. From the 1970s onwards, the majority of Americans graduated from some kind of higher education institution. 


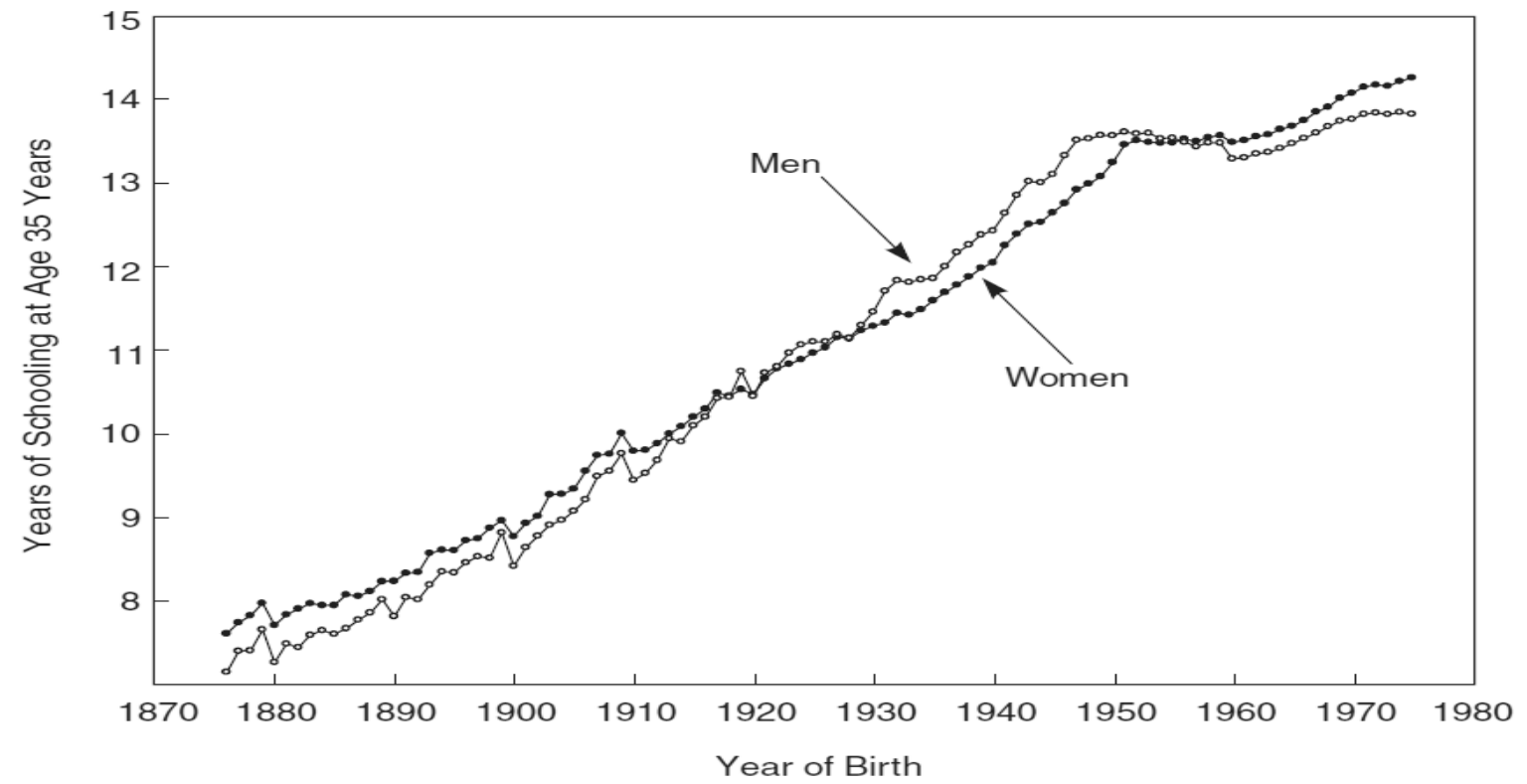

Fig. 1 Years of Schooling by Birth Cohorts, US Native-Born, by Sex, 1876 to 1975 . This figure plots the mean years of completed schooling for US native-born residents by birth cohort and sex, adjusted to age 35 using the approach described in the notes to Figure 1.4. Sources: 1940 to 2000 IPUMS. Reprinted by permission of the publishers from The Race between Education and Technology, by Claudia Goldin and Lawrence Katz, p.21, (Cambridge, Mass.: The Belknap Press of Harvard University Press), Copyright @ 2008 by the President and Fellows of Harvard College.

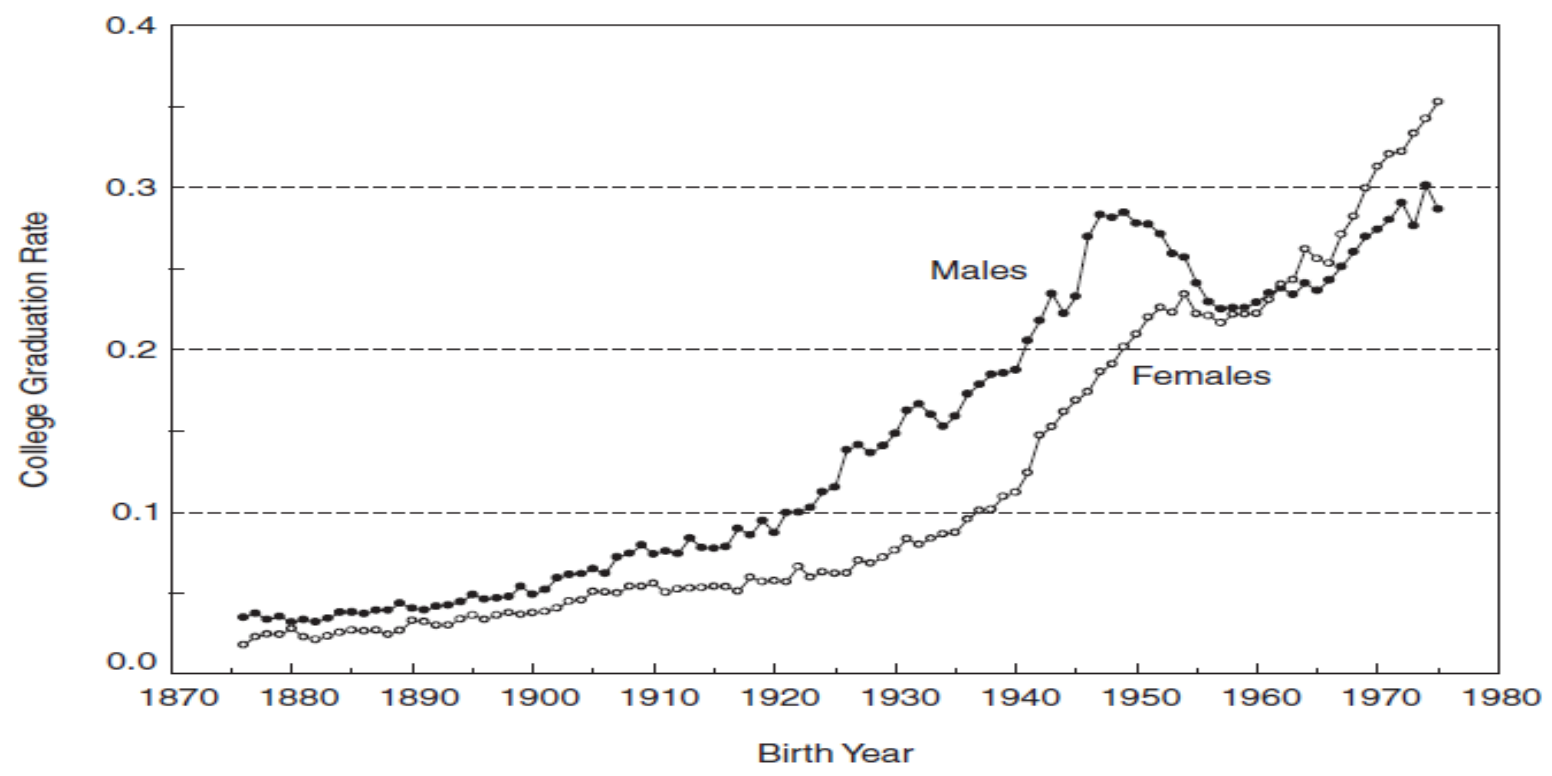

Fig. 2 College Graduation Rates for Men and Women: Cohorts Born from 1876 to 1975 (by Age 30). The figure plots the fraction of each birth cohort, by sex, that had completed at least four years of college by age 30 for the US-born. Since educational attainment data was first collected in the US population censuses in 1940, we infer completed schooling at age 30 for cohorts born prior to 1910 based on their educational attainment at older ages. Because we do not observe all post-1910 birth cohorts at exactly age 30, we use a regression approach to adjust observed college graduation rates for age based on the typical proportional lifecycle evolution of educational attainment of a cohort. The details of age- 
adjustment method can be found in DeLong, Goldin, and Katz (2003, figure 2-1). College graduates are those with 16 or more completed years of schooling for the 1940 to 1980 samples and those with a bachelor's degree of higher in the 1990 to 2005 samples. The underlying sample includes all US-born residents aged 25 to 64 years. Sources: 1940 to 2000 Census IPUMS; 2005 CPS MORG. Reprinted by permission of the publishers from The Race between Education and Technology, by Claudia Goldin and Lawrence Katz, p.249, (Cambridge, Mass.: The Belknap Press of Harvard University Press), Copyright (C) 2008 by the President and Fellows of Harvard College.

The historically very early and successful provision of an egalitarian and open system of school education and in particular the rapid speed of the expansion of higher education resulted not only in the unparalleled educational attainment of the US population, but also generated a large supply of high-skilled workers. In 1915, elementary school graduates made up almost 80 percent of the labour force. In 2005, contrastingly, college and university graduates constituted the majority of workers with about 60 percent. Notably, the rapid expansion of college graduation substantially transformed the distribution of educational attainment of men and women in the US population (Figure 3) thereby replacing poorly skilled by highly-skilled workforce (Goldin \& Katz, 2008, p. 34).

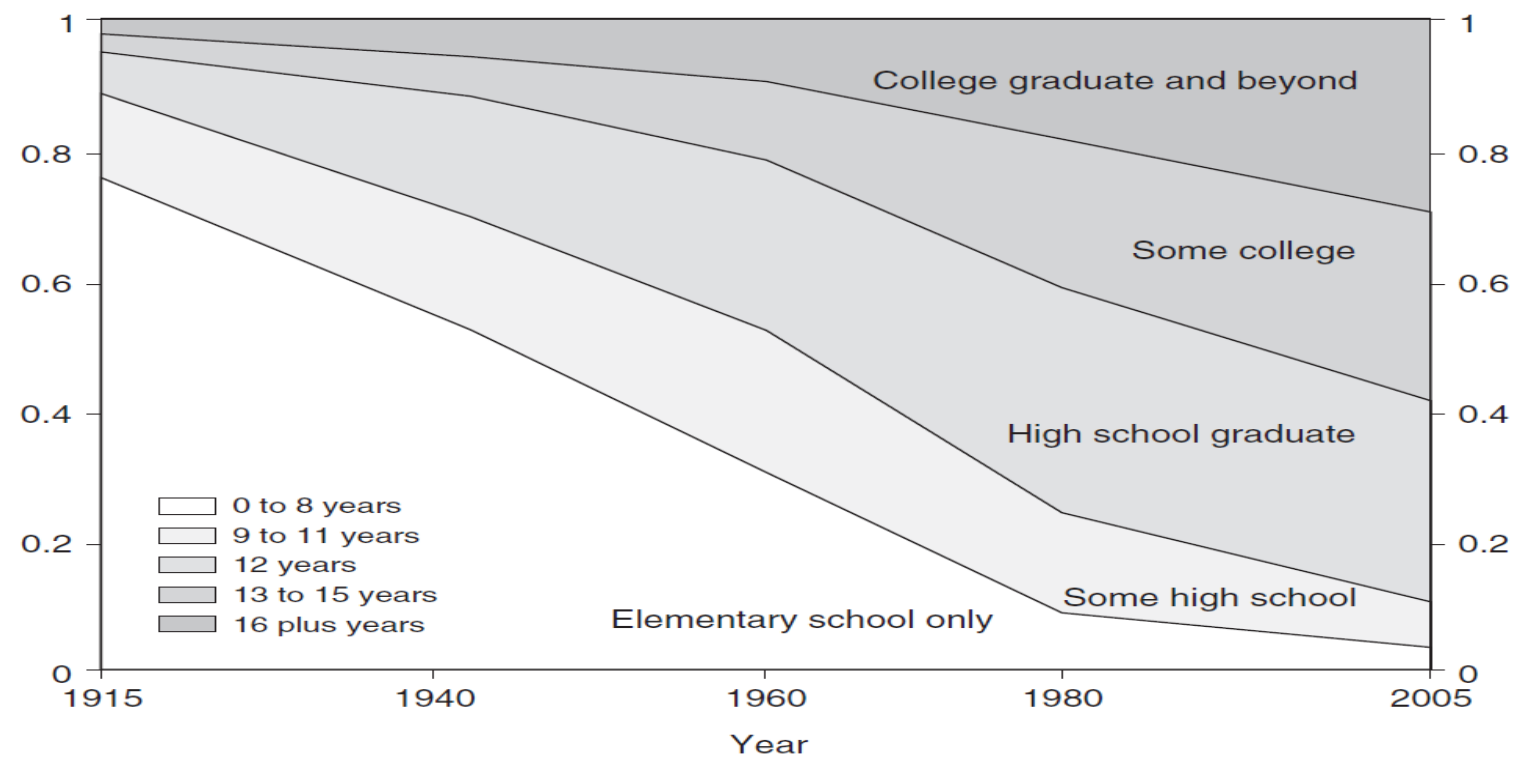

Fig. 3 Distribution of Educational Attainment of the Workforce, 1915 to 2005. Sources: 1915 lowa State Census; 1940, 1960, and 1980 Integrated Public Use Microsamples (IPUMS) of the US federal population censuses. 2005 Current Population Survey (CPS), Merged Outgoing Rotation Groups (MORG). 1915 US data are extrapolated from the 1915 lowa data. U.S. mean years of education for 1915 is given by the US mean for 1940 minus the difference between 1940 and 1915 means for lowa. The fraction, by years, is an extrapolation from the lowa data that is scaled to sum to one. Reprinted by permission of the publishers from The Race between Education and Technology, by Claudia Goldin and Lawrence Katz, p.34, (Cambridge, Mass.: The Belknap Press of Harvard University Press), Copyright (C) 2008 by the President and Fellows of Harvard College.

To sum up: The rising level of education created a higher level of individual labor productivity and this in turn fostered a higher rate of growth of the gross national product at the aggregate level (Goldin \& Katz 2008). As a result of this transformation of education and labor, 
the per capita income in 2000 was six times above the income level of 1900. At the same time, social inequality more than halved.

However, how should the development of gender differences in the field of education and earnings throughout the last decades be summarized? The Women's Bureau of the Department of Labor of the United States of America highlights the following points: "The gender earnings ratio (women's earnings as a percentage of men's earnings) for full-time, year-round workers improved from 60.2 percent in 1980 to 79.6 percent in 2015. Progress towards closing the disparity between women's and men's earnings was greatest during the 1980s, but slowed during the 1990s and 2000s. The earnings disparity between women and men is narrowest for young workers ages 25-34 and widest for workers ages 55 to 64." "The gender wage gap among those with the highest level of educational attainment is larger than the average wage gap for all workers" (U.S. Department of Labor, 2016, p.1). ${ }^{10}$

\section{Limits?}

The dynamic development of secondary and higher education significantly contributed to the leading economic position of the United States ahead of the former European competitors France, Germany, and Great Britain. However, the extraordinary and fascinating rise of educational attainment in the United States came to an end a generation ago. From then on, rates of enrollment declined, returns on educational investments decreased and social inequality in terms of educational performance remained permanent (4.1). Furthermore, press coverage of education waned considerably on the front pages of U.S. and other Western newspapers throughout twentieth century, signaling a dwindling rank of this issue in the print media (4.2).

\subsection{Rates of Enrollment, Returns on Education Investments and Inequality}

Since the 1980s, the growth of returns on national educational investments began to decline. Whereas between 1900 and 1980 the direct effect of education on the national economic growth reached an average 0.6 percent annually, this effect decreased to 0.3 percent in the last 35 years (Goldin \& Katz, 2008, p.38f). Furthermore, the quality of education has lost ground in the United States as shown by TIMSS, PISA, and other indicators. The previously superior American education system has been successfully challenged by global competitors.

The rise and limits of the United States' education system are well reflected by the history of establishing new institutions of schooling. Throughout the nineteenth century, the establishment of higher education institutions in the United States at first rapidly accelerated, reaching a peak in about 1890 with more than ninety new institutions for each five-year period. From this point on the number of newly erected higher education institutions dropped. There is only one short-term exception, a smaller peak with about 50 new establishments in the 1960s, the time of the campus revolts of the baby boomers. However, the rate of newly established educational institutions fell to almost zero at the end of the twentieth century (Figure 4). 


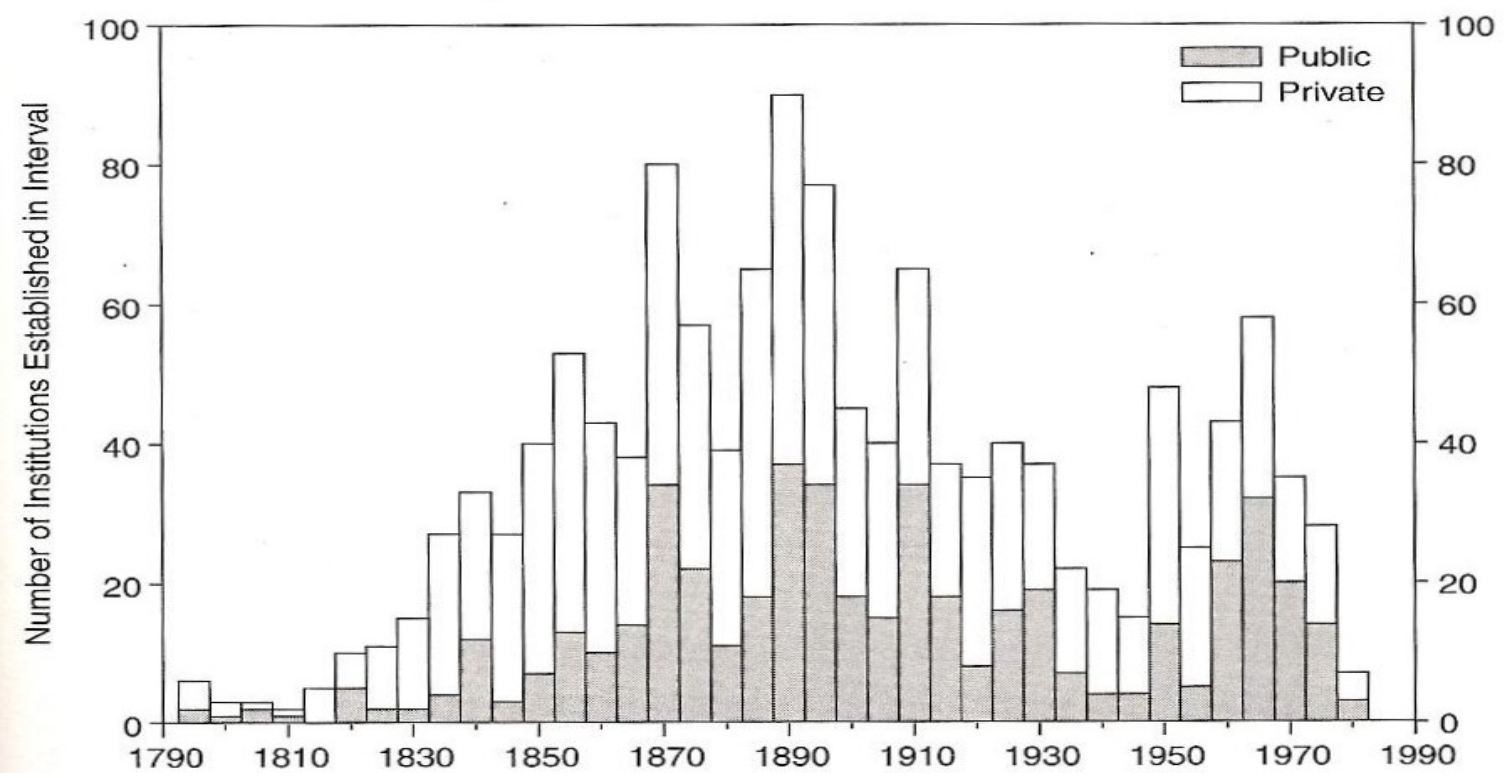

Fig. 4 Establishment Dates of Institutions of Higher Education, 1790 to 1990. The data refer to institutions in existence in 1992 and founded after 1789, to truncate the thin left tail of the distribution for ease of viewing. The establishment date may be different from the opening date and also from the date at which the institutions awarded a bachelor's degree. When an institution was formed out of one or several existing institutions the establishment date of the newly created institution is generally given, which would tend to shift the distribution a bit to the right. Source: Higher Education Publications (1992). Reprinted by permission of the publishers from The Race between Education and Technology, by Claudia Goldin and Lawrence Katz, p.257, (Cambridge, Mass.: The Belknap Press of Harvard University Press), Copyright (C) 2008 by the President and Fellows of Harvard College.

For a long period of time, the growth in the number of higher education institutions went hand in hand with ever-higher rates of college participation by each subsequent birth cohort. In the twentieth century, college participation per birth cohort increased from 30 to 60 percent on average. In the last decades however, college attendance stagnated. In particular, the college participation rate of immigrants never accomplished equality with natives (Figure 5). For this reason, the college participation rates of middle class and minority groups of the population show a growing disparity. Whereas the overall college participation is about 60 percent on average, immigrant minorities' college participation is 40 percent only. For decades, there has been no further progress of equality in terms of college participation rates. 


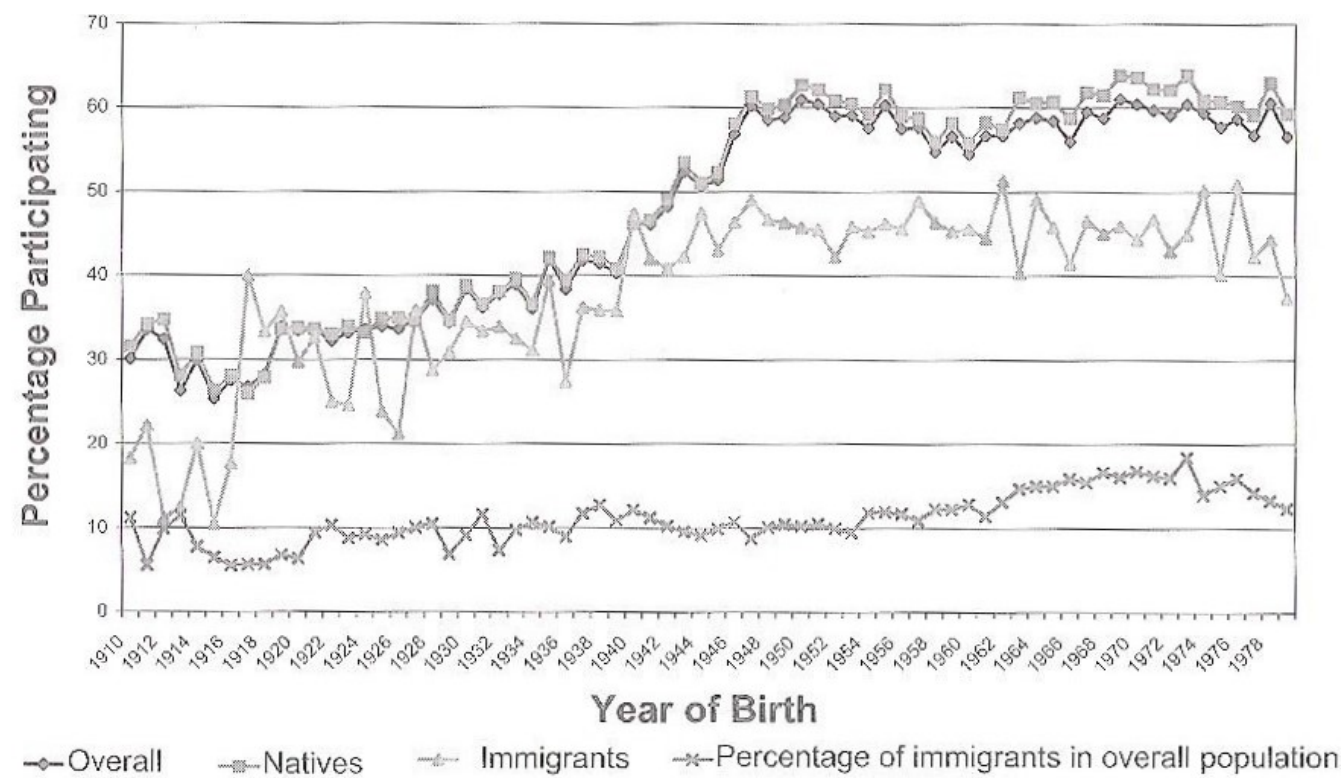

Fig. 5 College Participation Rate by Year of Birth. Source: Data from 2000 Current Population Survey. Reprinted by permission of The MIT Press from Heckman, James J., and Alan B. Krueger (2004). Edited by Benjamin M. Friedman. Introduction by Benjamin M. Friedman, Inequality in America: What Role for Human Capital Policies? p.80, Copyright @ 2004 by Massachusetts Institute of Technology.

As a consequence of rising inequality in the field of education, hourly earnings in the United States became more unequal as well. The differentiation of wage premiums by level of education is remarkable. Since the 1970s, hourly earnings of high school leavers without a high school diploma decreased. In addition, the wage premium of high school graduates decreasedfrom about 17 to 15 dollars. Even some years of college attendance now generate less return on education than in the 1970s. The income development of college graduates is not much better, whose educational returns stagnated in fact. Only the very advanced degrees of graduate schools are still profitable in terms of generating rising income (Figure 6). 


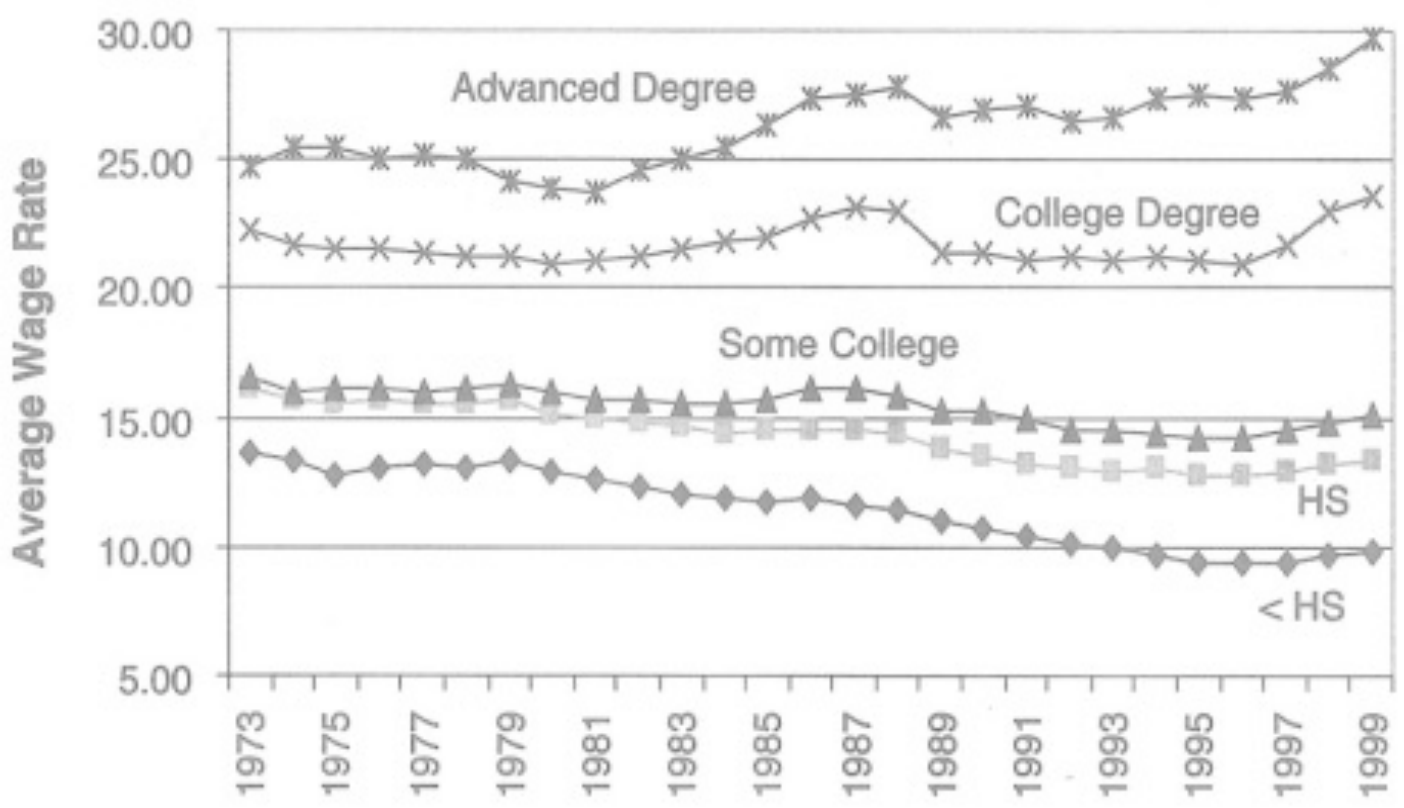

Fig. 6 Average Hourly Earnings by Level of Education, Men (1999 USD). Source: Economic Policy Institute Analysis of Current Population Survey Data. Reprinted by permission of The MIT Press from Heckman, James J., and Alan B. Krueger (2004). Edited by Benjamin M. Friedman. Introduction by Benjamin M. Friedman, Inequality in America: What Role for Human Capital Policies?, p.4, Copyright (c) 2004 by Massachusetts Institute of Technology.

In the wake of the inequality of hourly earnings of individuals, the inequality of real family annualized income growth has also increased. In the years 1940 to 1960, the lower strata of society enjoyed the highest income growth (3.0 percent annually) ahead of middle and top strata (2.4 percent). In later years, things reversed (Figure 7). Since the 1970 s, the top stratum of society enjoys the highest income growth (3.0 percent per year) whereas it is smallest in the bottom stratum (0.7 percent per year).

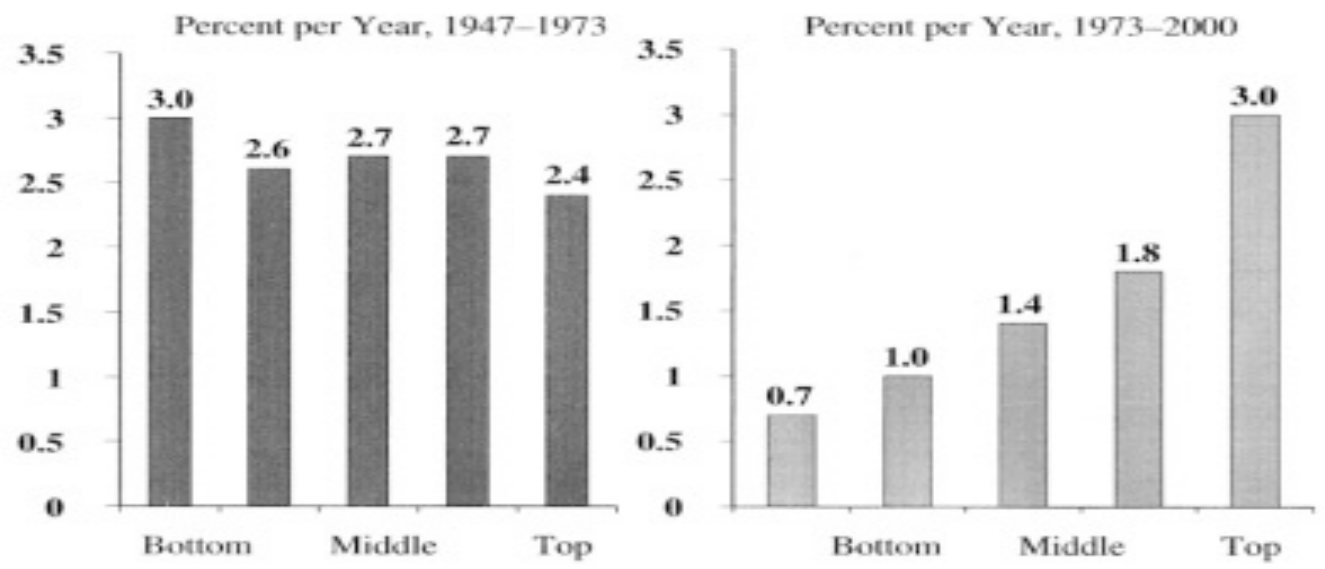


Fig. 7 Real Family Annualized Income Growth by Quintile, Post-war Period. Source: Census Bureau. Reprinted by permission of The MIT Press from Heckman, James J., and Alan B. Krueger (2004). Edited by Benjamin M. Friedman. Introduction by Benjamin M. Friedman, Inequality in America: What Role for Human Capital Policies?, p.6, Copyright (C) 2004 by Massachusetts Institute of Technology.

The development of real family income growth is reflected in the top percentile's share of income in the US. In the beginning of the twentieth century, the top percentile's share of income was about twenty percent. From then on, this share decreased to only eight percent. Yet, since the 1970s inequality increased once more, with the top percentile's share rising to fifteen percent (Figure 8).

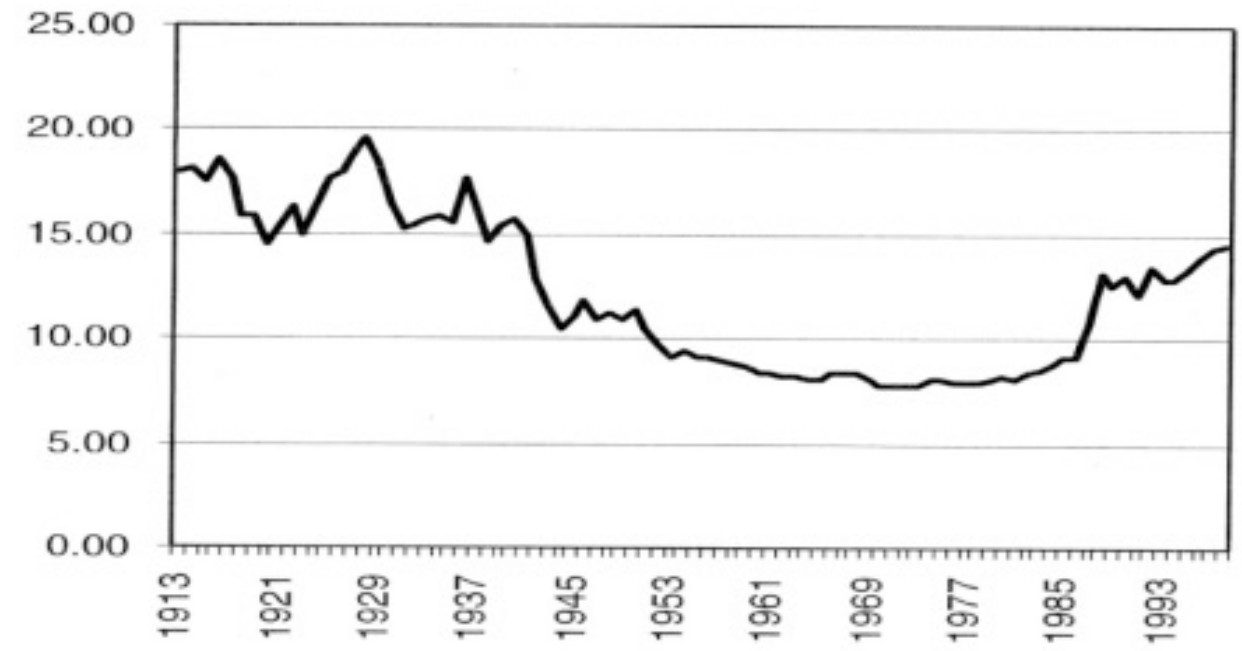

Fig. 8 Top Percentile's Share of Income in the United States, 1913 to 1998. Source: Piketty and Saez 2011, figure 3. Reprinted by permission of The MIT Press from Heckman, James J., and Alan B. Krueger (2004). Edited by Benjamin M. Friedman. Introduction by Benjamin M. Friedman, Inequality in America: What Role for Human Capital Policies? p.7, Copyright (C) 2004 by Massachusetts Institute of Technology.

There is reason to argue that the U.S. lead with respect to growing educational attainment, human capital returns, and educational equality has been under threat since the 1980s (National Commission on Excellence in Education, 1983). Since that decade the growth in educational attainment has slowed and plateaued, coupled with stagnating growth in productivity in terms of output per worker per hour. Whereas between 1900 and 1980, the direct effect of education on economic growth reached a maximum of 0.5 to 0.6 per cent annually, this effect decreased to 0.37 per cent in the final twenty years of the twentieth century (Goldin and Katz, 2008, p.38f). Furthermore, social inequality accelerated at a high rate after decades of growing equality. The US was surpassed by new competitors from Asia, in addition to some old European competitors, in terms of their productivity and economic growth, the quantity of educational attainment, and the quality of education as measured by the "Programme for International Student Assessment" (PISA) and the "Trends in International Mathematics and 
Science Study" (TIMSS). "Clearly, the United States no longer leads the world in the education of young adults" (Goldin and Katz, 2008, p.327).

\subsection{Waning press coverage of education and the welfare turn}

Provided that education significantly contributes to the nation's political, economic, and cultural strength and well-being, education and education policy should be prominent issues in the press, continuously displayed on the front pages of leading newspapers. The press should mirror the rise and limits of education and education policy in the twentieth century. We should expect to observe an increase of education coverage in the press accompanying the expansion of enrollment and graduation rates of the national education systems. And furthermore, in times of continued globalization, the coverage of international issues of education policy should grow faster than the coverage of domestic themes. However, studies have shown that this is not the case (Weymann 2014 and 2016). Instead, in the U.S. and other western states, a general decline of education coverage in the press is observed, along with a preponderance of domestic coverage rather than international.

We checked our assumptions by looking at the front-page coverage of education and education policy in Britain, France, Germany, and the United States as "Centers of Learning" (BenDavid, 1992; Clark, 2006) at the dawn and the dusk of the twentieth century. The analysis of front-page coverage of education begins with the first decade of the century, the years from 1900 to 1909. This decade best represents the heyday of the fully developed European national education state before Europe's decay during the 30 years of war from 1914 to 1945, and before the US took over Western hegemonic power. We will then compare the education coverage in the times of glorious nations at the beginning of the twentieth century with the front-page coverage of education in the second half of the century, the years from 1950 to 2004. The latter was a period in which the former European empires turned into semi-sovereign and polymorphous welfare states, and a period in which the hegemonic world power of the US passed its climax and became increasingly challenged by the rise of new economic, political, military, and scientific world powers.

The sample of articles consists of the front pages of the first Saturday edition of each quarter (January, April, July, and October) of the Frankfurter (Allgemeine) Zeitung ${ }^{11}$ (Germany), the Times ${ }^{12}$ (England), the New York Times (US), and Le Figaro (France). The selected newspapers were continuously published throughout the entire century, including the years 1900 to 1909 and 1950 to $2004 .{ }^{13}$ The Saturday editions are the most voluminous and comprehensive editions of the week, covering a large number of topics ${ }^{14}$. The sample size is 40 editions per newspaper in the period 1900 to 1909, respectively 160 editions in total for all four newspapers in this first period of observation. In the second period of 1950 to 2004, the sample runs up to 220 editions per newspaper, respectively 880 editions for all four newspapers. The total sample of the entire period 1900 to 2004 is 260 editions per newspaper or 1040 editions for the four papers together.

At the beginning of the twentieth century, there was more extensive and detailed press coverage of education and education policy on the front pages of leading Western newspapers than today. This can be seen from an analysis of the Frankfurter Allgemeine, Le Figaro, the New York Times, and The Times. Uniformly, these newspapers' coverage of education and education policy on front pages decreased substantially throughout the century - from over fifty articles per year in the first decade of the century to less than twenty in the second half of the century 
(Figure 9). In particular, coverage of international educational affairs became very small, decreasing from forty percent share of all articles on education to almost zero (Figure 10).

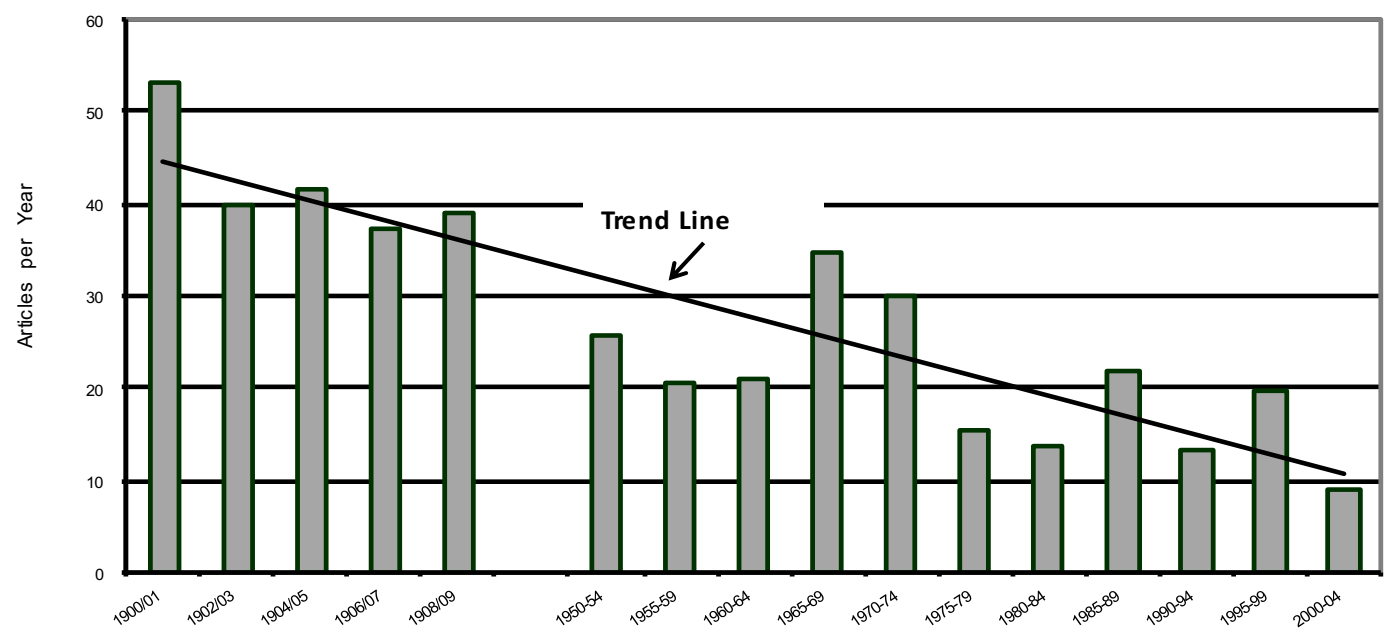

Fig. 9 Annual Front-Page Coverage of Education, 1900 - 1909 and $1959-2004$ (Own calculations)

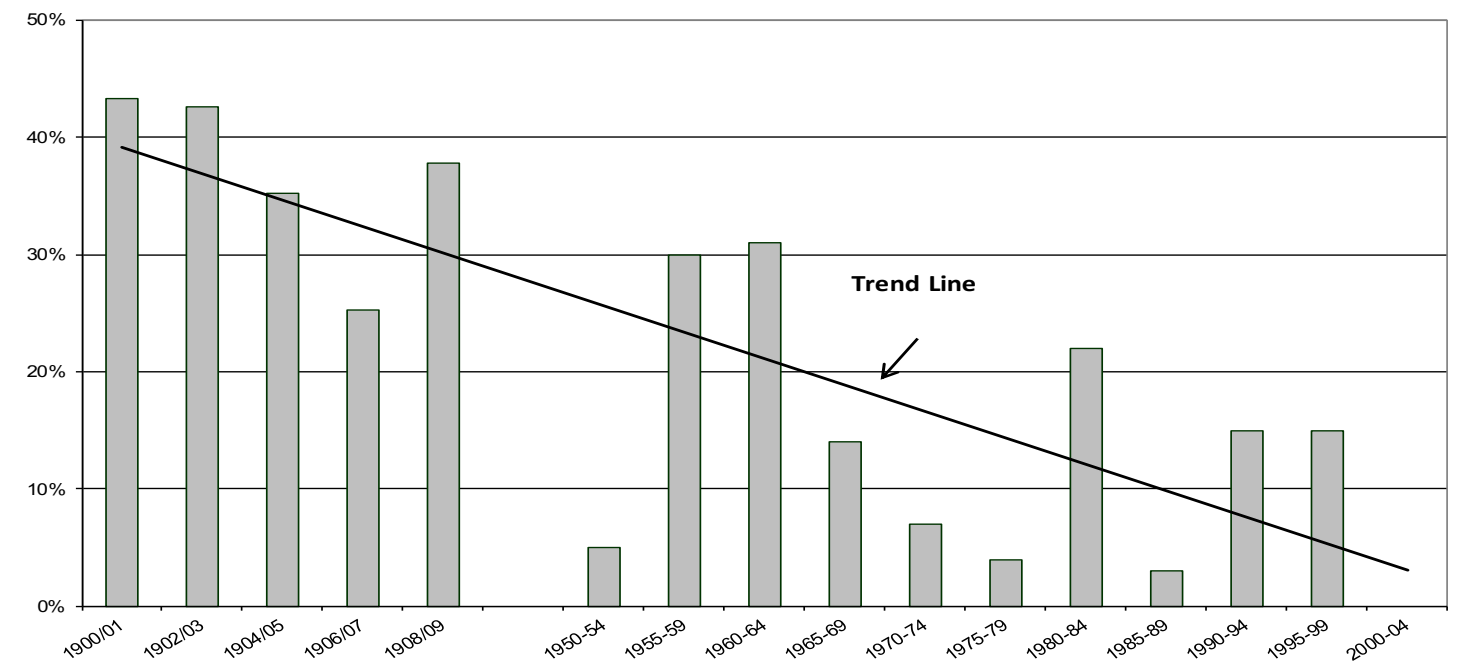

Fig. 10 Share of International Education in Percent of All Education Coverage (Own calculations)

The decrease of press coverage of education in general and particularly of international affairs of education reflects the transformation of education from a key policy instrument of glorious and victorious nations to a domestic panacea tool of caring welfare states.

The first decade of the twentieth century was a time of triumphant western hegemonic nations and empires, marked among other characteristics by a strong trust in the future benefits of education and education policy. The newspapers optimistically view education as a promising means to improve national strength and the international competitiveness in terms of wealth, power, industry, commerce, finance, science, technology, vocational skills, culture and military. Contrastingly, in the second half of the century, education policy served primarily as a popular 
instrument of the welfare state against the alleged social ills of modern society. Education is now regarded as a panacea, suitable for healing and compensating ever more diverse evils of contemporary society. The articles now focus primarily on social problems like unemployment, inequality, migration, integration, poverty, health, drugs, crime, violence, gender, etc. At the same time, newspapers increasingly put in doubt the ability of education and education policy to solve such problems successfully, because these problems turned out to be enduring and persistent for decades or even throughout the entire twentieth century.

Indeed, education policy is a protracted process of very long durée. The interim shift of attention from human capital investment to social problems and welfare policy has had consequences: Setting the course of national and social progress via education and education policy made it to the front page, yet the mess of unsolved educational problems in contemporary welfare societies does not.

\section{Western and Non-Western Globalization}

We have argued in the beginning that education policy is a core element of the modern state's sovereignty and autonomy. Education serves the state as a means of integrating society, as a key tool for improving political power and legitimacy, and finally stimulating economic growth via human capital investment. However, in the last decades, the declining growth of individual and aggregated human capital returns, problems of reducing social inequality as well as deficient cultural and social integration became visible. This negative development was accompanied by a waning interest of leading American, British, French and German newspapers to put matters of education on the front-page.

Has the remarkable historical rise of education and education policy reached limits of growth in Western nations because we are in the transition from Western to Non-Western Globalization? Globalization is not a new phenomenon. However, the turn towards strong nonwestern globalization is a new phenomenon. Throughout centuries there was only a permanent interplay between the progressive western globalization of the economy, political power and cultural hegemony and the development of a global education policy. To cite a publication of 1895 (Hunter, 1895): "State education for the people in America, Europe, India, and Australia" with a focus on the education of women, technical instruction, and payment by results is neither a new field of policy nor a new object of science at the turn of the century.

The nineteenth's century empires saw state education for the people in the colonies as an ordinary task and an important political instrument (Green 2013; Middleton \& Weitzman, 1976; Weymann 2014). The intention of colonial education policy to improve the growth of economy, to support the legitimacy of political power, and to facilitate cultural integration was routine. However, means, institutions and quality of education in the dependent territories varied considerably over time and space as shown by the examples of Africa, Austria-Hungary, Canada, China, India, Ireland, the Ottoman Empire, Russia (c.f. Hunter, 1895; Leonhard, J. \& Hirschhausen, U. von, 2011; Raftery \& Fischer, 2014).

In London, The Time complains that in the British Empire colonial education policy "is still in its infancy and private generosity is required" (The Times, 1 October 1904). In Africa, racist positions prevail: Sir John Gorst, M.P. was certain "that in dealing with uncivilized races the most important thing was to teach them what they ought to do" (The Times, 7 October 1905). Concerning India, education was expected to contribute to the "moral and intellectual 
regeneration of the people" by establishing "our language, our learning and ultimately our religion" (Ferguson, 2003, p.143). "It was well for India and for the Empire as a whole that [...] the Mahomedans had abandoned their traditional reserve, and had realized that in a new world a new policy of effort was required" (The Times, 3 April 1909).

Other colonial powers like France, the Netherlands or Germany are seen as major rivals challenging the UK in the field of colonial education in South Africa, China and elsewhere. On 3 July 1909 the paper raises the question: "Why does (the British) government not support the Hong Kong university scheme in the same way the German government is supporting a similar scheme at Kiao-Chau?" "The Germans, though the last comers, have set to with their usual systematic thoroughness. The latest official report of the German authorities at Kiao-Chau contains instructive details concerning the high school that is about to be created there for the Chinese students. Though in name only a high school, its scope is even larger than that of the proposed University of Hong-Kong." The Times reports that the "Hochschule" ${ }^{15}$ includes a medical and technical branch, agriculture, forestry, political science, international law, state and administrative law, mining and maritime law, political economy, and finance.

The globalization of education generated strong antagonism almost everywhere. On the one hand, the increase in the value of human capital induced young people, women, lower classes, nations, ethnicities, religious groups and other sections of society to invest in education. Thus, education facilitated and enforced economic inclusion, political integration, and cultural assimilation. On the other hand, the same process also spurred political conflicts by setting autonomy, identity and cultural difference against homogenization and submission to the empires' interests and rules (Burbank \& Cooper, 2010; Bayly, 2004).

At the level of primary schools the empires' intentions to form a loyal population through extended schooling and teaching an inclusive patriotic myth failed. The establishment of elementary education in the colonies was accompanied by the unintended side effect of politicizing the hitherto non-literate or minimally educated population in the social and geographic periphery. At the level of higher education, education policy aimed at achieving a stronger centralization of the empire through training a class of loyal indigenous elites. For Britain, for example, the means to achieve this goal in India was the education of pro-British elites as interpreters between the British and the millions the Empire ruled: "Indian in blood and colour, but English in taste, opinions, in morals, and in intellect" (Ferguson, 2003, p.190). But again, higher education enhanced opportunities to build up independent elite networks and indigenous hierarchies within the empires' internal power structure. On both tiers of education, elementary and higher, education policy unintentionally facilitated and strengthened opposition against the hegemonic nation.

"When the twentieth century opened European power in Asia and Africa stood at its Zenith. Sixty years later only the vestiges of European domination remained (...)" (Arrighi, 2007, p.1). Today, education is globally intertwined in multiple ways with the forces of states, politics, markets, professions, sciences as well as with political, social and cultural movements. Education has become a global 'politicum', a highly relevant political issue in accordance with the Western model; an indispensable element of societal reproduction and progress. The result of this development is a tendency towards the global isomorphism of education.

Permanent global competition favors general, analytical, and less job-specific skills and competences. Life time spent in educational institutions is expanding everywhere and is 
organized in universal sequences from preparatory school, via elementary and secondary school to higher education. Best practice models stimulate strong interest in ranking, and benchmarking of education politics, curricula, people and institutions. International organizations and networks of homogeneously educated elites also execute a strong impact on isomorphism of professional activities. Through international actors in industry, trade, finance, transport, communication, law, bureaucracy, science, and technology, the professional rationality of higher education establishes itself on a global scale implementing isomorphic ideas and institutions of sciencebased education (Martens, K., Rusconi, A., Leuze, K. (Eds.) (2007); Martens, K., Nagel, A-K., Windzio, M, Weymann, A. (Eds.) (2010)).

Generally speaking, the history of education and education policy is a great success story - in Europe, the West and ultimately worldwide. The progress of tertiary education in particular is closely related with the rising prosperity of many countries of the world. On average, high income countries have a high tertiary education rate of 75.10 percent whereas low income countries have low tertiary education rates of 9.18 percent only (Table 3). Yet, no strong linear relationship exists between tertiary education rates and national prosperity. ${ }^{16}$ For example, the United States has a tertiary education rate of 95.33, the similarly prosperous countries Germany, Switzerland and Luxembourg however have tertiary education rates of only $61.65,55.56$ and 18.20 percent respectively. The variance of higher education rates is very high within this group of high income countries. The same is also true for the group of low income countries. Poor countries like Greece and North Korea have extremely high tertiary education rates of 113.98 and 100.80 respectively, whereas Puerto Rico has a rate of 86.46 and Niger of only 1.75 percent respectively.

\begin{tabular}{|ll|}
\hline Country & Tertiary Education Rate \\
\hline High Income Countries & $\mathbf{7 5 , 1 0}$ \\
Low Income Countries & $\mathbf{9 , 1 8}$ \\
USA & 95,33 \\
Germany & 61,65 \\
Switzerland & 55,56 \\
Luxembourg & 18,20 \\
Greece & 113,98 \\
Korea (North) & 100,80 \\
Niger & $\mathbf{1 , 7 5}$ \\
Puerto Rico & $\mathbf{8 6 , 4 6}$ \\
\hline
\end{tabular}

Table 3 National Prosperity and Tertiary Education Rates in 2012. Source: World Bank; UNESCO World Development Indicators. October 2015. Schooling Following Secondary School Leaving. Percent Gross.

In section 3 above on the 'Human Capital Century' and the expansion of higher education the expansion of tertiary education enrollment as a key characteristic of the twentieth century was emphasized. Now, in the twenty-first century, enrollment in tertiary education is accelerating even more quickly. Whereas in 2000 the global enrollment rate in tertiary education was 19.03 percent for both sexes, in 2015 this rate runs up to 35.60 percent. The higher education rate has almost doubled in only 15 years. Women's tertiary education rate increased even faster 
than men's rate - rising from 18.97 percent in 2000 to 37.70 percent in 2015 thereby outperforming males (Figure 11).

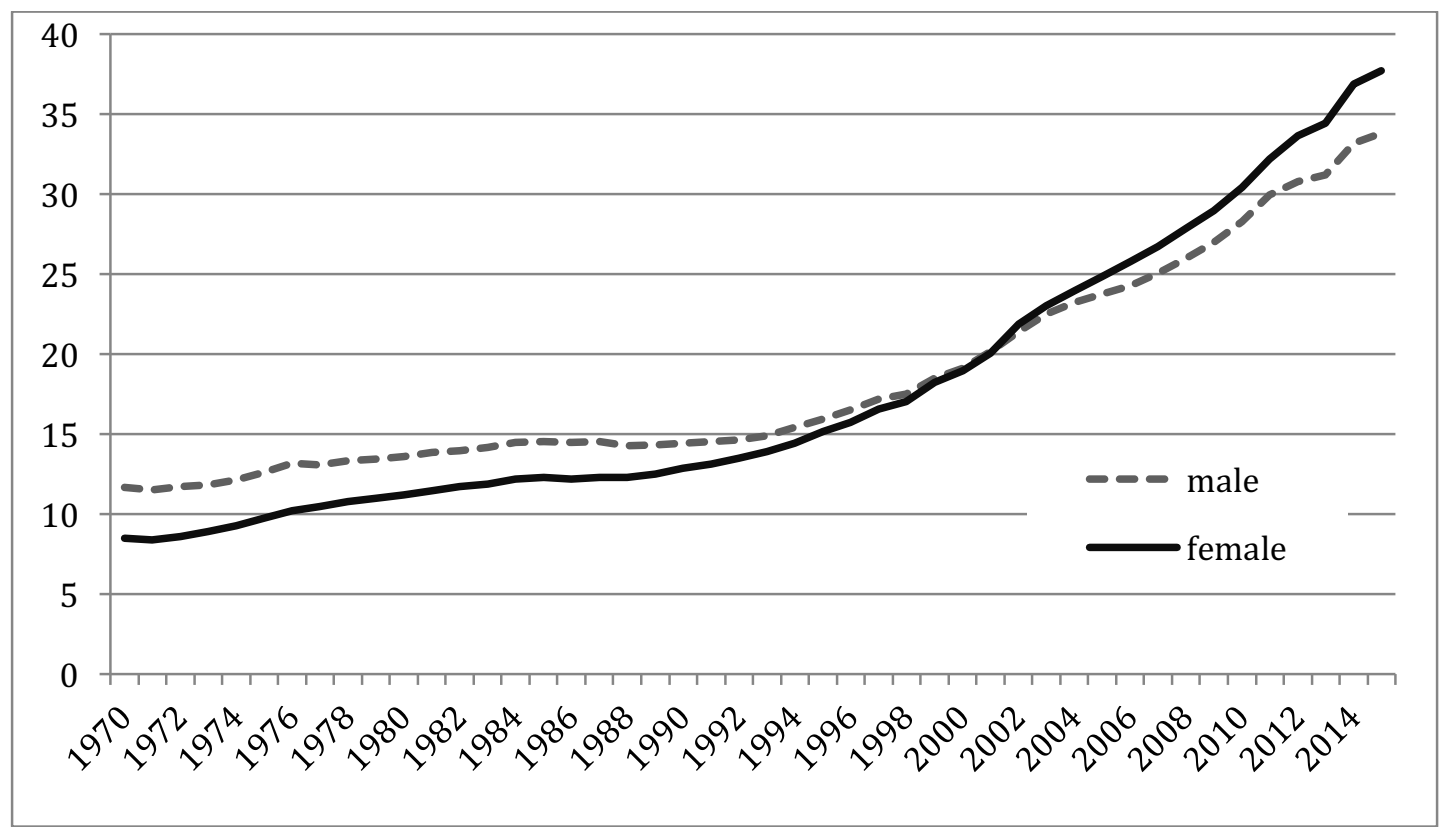

Fig. 11 Gross Enrollment Ratio, Tertiary, Both Sexes (\% Gross). 1970 to 2016. Sources: United Nations Educational, Scientific, and Cultural Organization (UNESCO). Institute for Statistics

\section{Antagonism of Global and National Education. Final Considerations}

The integration of nations and individuals of the world through inclusion in the global political economy is profound and unlimited. The prices of consumer goods, capital, human capital, commodities, and labor converge - such that one could say that Adam Smith has arrived in Beijing and elsewhere in the world (Arrighi, 2007). Education certificates are no exception. Globalization undermines the value of hitherto nationally protected meritocratic entitlements acquired in domestic educational institutions. Global markets continually evaluate education credentials and ascribe them with ranking positions which make professional skills and competences of their holders comparable and often also visible in public. That way, they subjugate previously protected national educational credentials to world market conditions and demands. In fact, "the isomorphic processes that now frame education policy are often constituted globally and beyond the nation-state, even if they are still articulated in nationally specific terms" (Rizvi \& Lingard, 2010, p.3). ${ }^{17}$

Any further progressive globalization of capital and human capital challenges the hitherto national prerogative of education. Through global forces, the multifaceted time-honored patterns of traditional education are uniformly transformed in the direction of tradable human capital, technically useful knowledge, career-specific qualifications, general performance orientation and communicative competence. Yet previously highly valued traditions of education do not disappear completely, but continue to exist in parts. They are perpetually reinforced in the pursuit of national, nationalist, ethnic, religious, class and milieu specific interests, worldviews, convictions and ideologies. 
Due to these ambiguous effects of globalization, the isomorphic development of educational goals, curricula, institutions and professional staff does not simultaneously and inevitably lead to cosmopolitanism (Meyer \& Rowan, 1977). Isomorphism and cosmopolitanism are neither identical nor do they mutually generate each other. On the contrary, the evolution of global isomorphism of educational institutions, curriculum, and the teaching profession was and is in perpetual conflict with vested educational interests and worldviews of individuals, nations, religions and a vast variety of minorities. The interplay of traditional patterns of education with universal forces of educational globalization is characterized by antagonistic dynamics. Yet, just this antagonist dynamics of global and national forces are driving forward the transformation of education and society - with open end.

In a nutshell: One hundred years ago, at the beginning of the twentieth century, Western nations enjoyed a unique historical period of supremacy in terms of political sovereignty, economic growth, cultural hegemony and military strength. Today, globalization, once driven by imperial and hegemonic Western powers, has been transformed into non-Western globalization. Non-Western globalization has gained historical momentum and is expedited by newly ascending nations in search of a greater piece of the global pie. As before, continued globalization executes a strong impact on individuals, nations, religions, and ethnicities and thereby stimulating progress and losses, optimism and resentments. In response, the nation-state is strengthened as a defensive mechanism against presumed and real threats to stability, safety, identity, life, state and society.

At all times, the nation-state owes a great deal of its legitimacy from processes of globalization. Historically, the modern interventionist nation-state and the free flow of economic and human capital stand as polar opposites (James 2001). Therefore, any transnational education policy is difficult to implement, and global education policy is a cosmopolitan fiction for the time being.

\section{References}

Arrighi, G. (2007). Adam Smith in Beijing: Lineages of the Twenty-First Century. London: Verso Books.

Baker, D. (2014). The Schooled Society. The Educational Transformation of Global Culture. Stanford: Stanford University Press.

Bayly, Ch. A. (2004). The Birth of the Modern World, 1780-1914. Global Connections and Comparisons. Oxford: Blackwell.

Bellaigue, Ch. de (Ed.) (2007). Educating Women. Schooling and Identity in England and France, 1800 - 1867. New York: Oxford University Press.

Ben-David, J. (1992). Centers of Learning: Britain, France, Germany, United States. New Brunswick, NJ: Transaction Publishers.

Burbank, J., \& Cooper, F. (2010). Empires in World History: Power and the Politics of Difference. Princeton, NJ \& Oxford: Princeton University Press.

Busemeyer, M. R. (2006). Die Bildungsausgaben der USA im internationalen Vergleich. Politische Geschichte, Debatten und Erklärungsansätze. Wiesbaden: Deutscher Universitätsverlag.

Chartier, R., Julia, D., \& Compère, M.-M. (1976). L'éducation en France du XVIe au XVIIle siècle. Paris: Société d'édition d'enseignement supérieur. 
Clark, W. (2006). Academic Charisma and the Origins of the Research University. Chicago \& London: The University of Chicago Press.

Comte, A. (1853; first published 1830-1842; reprinted in 2009). The Positive Philosophy of Auguste Comte, Volume 2. New York: Cambridge University Press.

Durkheim, É. (1938; reprinted 1977). The Evolution of Educational Thought: Lectures on the Formation and Development of Secondary Education in France. London: Routledge \& Kegan Paul.

Ferguson, N. (2003). Empire: How Britain Made the Modern World. London and New York: Penguin Books.

Goldin, C., \& Katz, L. (2008). The Race Between Education and Technology. Cambridge, MA \& London: The Belknap Press of Harvard University Press.

Graddy, K., \& Pistaferri, L. (2000). Wage Differences by Gender: Evidence from Recently Graduated MBAS. Oxford Bulletin of Economics and Statistics, 62, 837-854. Oxford \& Malden: Blackwell.

Green, A. (2013). Education and State Formation. Europe, East Asia and the USA. Houndmills, Basingstoke \& New York: Palgrave Macmillan.

Grendler, P. F. (2001). Schools and Schooling. In P. N. Stearns (Ed.), Encyclopedia of European Social History from 1350 to 2000, Volume 5, $5^{\text {th }}$ edition (pp. $\left.329-351\right)$. Detroit: Scribner.

Grew, R., \& Harrigan, P. J. (1991). School, State, and Society: The Growth of Elementary Schooling in Nineteenth-Century France. A Quantitative Analysis. Ann Arbor, MI: The University of Michigan Press.

Hall, J. A., \& Schroeder, R. (eds.) (2006). An Anatomy of Power: The Social Theory of Michael Mann. Cambridge, UK: Cambridge University Press.

Hammerstein, N., \& Herrmann, U. (2005). Handbuch der deutschen Bildungsgeschichte. Band II. 18. Jahrhundert. Vom späten 17. Jahrhundert bis zur Neuordnung Deutschland um 1800. München: C. H. Beck.

Hanushek, Eric A., \& Woessmann, L. (2015). The Knowledge Capital of Nations. Education and the Economy of Growth. Cambridge und London: The MIT Press.

Heckman, J. J., \& Krueger, A. B. (2003). Inequality in America: What Role for Human Capital Policies? Cambridge, MA. \& London: MIT Press.

Herrmann, U. (2005). Schlussbetrachtung. Das 18. Jahrhundert als Epoche der deutschen Bildungsgeschichte und der Übergang ins 19. Jahrhundert. In N.Hammerstein, \& U. Herrmann (Eds.), Handbuch der deutschen Bildungsgeschichte, Band II: 18. Jahrhundert. Vom späten 17. Jahrhundert bis zur Neuordnung Deutschlands um 1800. Munich: C.H.Beck.

Hunter, W. W. (1895). State Education for the People in America, Europe, India and Australia. The Education of Women, Technical Instruction, and Payment by Results. Syracuse, NY: C.W. Bardeen Publisher.

James, H. (2001). The End of Globalization: Lessons from the Great Depression. Cambridge, MA and London: Harvard University Press.

Kaelble, H. (2007). Sozialgeschichte Europas. 1945 bis zur Gegenwart. München: C.H.Beck.

Küpper, E. (1987). Die höheren Mädchenschulen. In N. Hammerstein and U. Herrmann (Eds.), Handbuch der deutschen Bildungsgeschichte, Band II. 18. Jahrhundert, pp. 180 to 191. Munich: C.H. Beck.

Lawson, J., \& Silver, H. (1973). A Social History of Education in England. London: Methuen \& Co. 
Leonhard, J., \& Hirschhausen, U. von (2011). Comparing Empires: Encounters and Transfers in the Long Nineteenth Century. Göttingen: Vandenhoeck \& Ruprecht.

Luther, M (1524). An die Ratsherren aller Städte deutschen Landes, daß sie christliche Schulen aufrichten und halten sollen. In W. Metzger (1996) Calwer Luther-Ausgabe, Band 4. Hänssler Verlag, Neuhausen-Stuttgart.

Luther, M. (1520). An den christlichen Adel deutscher Nation von des christlichen Standes Besserung. In N. Hammerstein (Ed.) (1991), Staatslehre der frühen Neuzeit. Frankfurt: Deutscher Klassiker Verlag.

Malthus, T. R. (1798; reprinted 2007). An Essay on the Principle of Population as it Affects the Future Improvement of Society. Mineola, New York: Dover.

Mann, M. (1986). The Sources of Social Power, Volume 1, A History of Power from the Beginning to $A D$ 1760. Cambridge, UK: Cambridge University Press.

Martens, K., Rusconi, A. Leuze, K. (Eds.) (2007). New Arenas of Educational Governance. The Impact of International Organizations and Markets on Educational Policy Making. Houndmills, Basingstoke \& New York: Palgrave Macmillan.

Martens, K., Nagel, A-K., Windzio, M, Weymann, A. (Eds.) (2010). Transformation of Education Policy. Houndmills, Basingstoke \& New York: Palgrave Macmillan.

Mayer, C. (2005). Erziehung und Bildung für Mädchen. In N. Hammerstein and U. Herrmann (Eds.), Handbuch der deutschen Bildungsgeschichte, Band II. 18. Jahrhundert, pp. 188 to 211. Munich: C.H. Beck.

Maynes, M. J. (1985). Schooling in Western Europe: A Social History. Albany, NY: State University of New York Press.

Melanchthon, P. (1543). Oratio de dignitate legum. In N. Hammerstein (Ed.) (1991), Staatslehre der frühen Neuzeit. Frankfurt: Deutscher Klassiker Verlag.

Meyer, J. W. \& Rowan, B. (1977). Institutionalized Organizations: Formal Structure as Myth and Ceremony. American Journal of Sociology (83), 340-363. Chicago. University of Chicago Presse.

Middleton, N., \& Weitzman, S. (1976). A Place for Everyone: A History of State Education from the End of the 18th century to the 1970s. London: Gollancz.

Mussida, C., \& Picchio, M. (2012). The Gender Wage Gap by Education in Italy. IZA Discussion Paper No. 6428, Bonn: IZA, 1-31.

National Commission on Excellence in Education (1983). A Nation at Risk: The Imperative for Educational Reform. Washington, DC: United States Department of Education.

Neugebauer, W. (2005). Niedere Schulen und Realschulen. In N. Hammerstein \& U. Herrmann (Eds.), Handbuch der deutschen Bildungsgeschichte, Band II: 18. Jahrhundert. Vom späten 17. Jahrhundert bis zur Neuordnung Deutschlands um 1800. Munich: C.H.Beck.

Pitts, J., \& Kroncke, C. (2014). Educational Attainment and the Gender Wage Gap: A Comparison of Young Men and Women in 1984 and 2007. Journal Forum for Social Economics, 43 (2), 123-155. Milton Park. Abingdon \& New York: Taylor \& Francis.

Pufendorf, S. (1667/1669). De statu imperii Germanici. In N. Hammerstein (Ed.) (1991). Staatslehre der frühen Neuzeit. Frankfurt: Deutscher Klassiker Verlag.

Raftery, D., \& Fischer, K. (2014). Educating Ireland. Schooling and Social Change, 1700-2000. Sallins, Co. Kildare: Irish Academic Press.

Rizvi, F., \& Lingard, B. (2010). Globalizing Education Policy. New York: Routledge. 
Rothblatt, S., \& Wittrock, B. (Eds.) (1993). The European and American University Since 1800. Cambridge, UK and New York: Cambridge University Press.

Schultz, T. W. (1981). Investing in People: The Economics of Population Quality. Berkeley, Los Angeles \& London: University of California Press.

Seckendorff, V. L. von (1656). Teutscher Fuersten-Stat. In N. Hammerstein (Ed.) (1991), Staatslehre der frühen Neuzeit. Frankfurt: Deutscher Klassiker Verlag.

Smith, A. (1776, reprinted in 1974). The Wealth of Nations. Harmondsworth, UK: Penguin Books. Seregny, S. J. (2001). Teachers. In P. N. Stearns (Ed.) Encyclopedia of European Social History from 1350 to 2000, Vol. 5. Detroit: Charles Scribner's Sons.

Trow, M. A. (2010). Twentieth-Century Higher Education: Elite to Mass to Universal. Edited by Burrage, M. Baltimore, MD: Johns Hopkins University Press.

U.S. Department of Labor. Women's Bureau. (2016). Women's Earnings and the Wage Gap, Issue Brief, 1-27.

Weymann, A. (2014). States, Markets and Education. The Rise and Limits of the Education State. Houndmills, Basingstoke \& New York: Palgrave Macmillan.

Weymann, A. (2016). Bildungsstaat. Aufstieg. Herausforderungen. Perspektiven. Wiesbaden: Springer.

Wimpfeling, J. (1501). Germania. In N. Hammerstein (Ed.) (1991), Staatslehre der frühen Neuzeit. Frankfurt: Deutscher Klassiker Verlag.

Woessmann, L., \& Peterson, P.E. (Eds.) (2007). Schools and the Equal Opportunity Problem. Cambridge: Massachusetts Institute of Technology Press.

Zymek, B., \& Neghabian, G. (2005). Sozialgeschichte und Statistik des Mädchenschulwesens in den deutschen Staaten 1800 - 1945. Datenhandbuch der deutschen Bildungsgeschichte, (Volume 2,3). Göttingen: Vandenhoeck \& Ruprecht.

1 Eloisa Harris, Werner Dressel and Matthias Wingens contributed to the article through valuable comments. Eloisa Harris and Werner Dressel proofread the English manuscript. Verena Weymann took care for the layout of tables and figures. For further information on the rise and limits of education policy see Weymann 2014.

2 For further information about this exclusive imperial right, see Pufendorf (1667/1669).

3 Cuius regio, eius religio (Augsburg Religious Peace, 1555). The meaning of this regulation is: The prince determines the religion of the people in his territory (translated from the Latin by Ansgar Weymann).

4 Veit-Ludwig von Seckendorff, statesman and jurist, constitutional law (1626-1692). His treatise follows Machiavelli's II Principe in as much as the manuscript represents the ideal patterns of a well-organized state. Concerning education, Seckendorff distinguishes between four grades or tiers of schooling: elementary schools, lower secondary Latin school, gymnasium, and the University, as the fourth and top grade.

5 Prussia is discussed here because Prussia may not have been the first German Land to introduce mandatory education for all citizens, but it was the most important one.

6 'Schulen und Universitäten sind Veranstaltungen des Staates [...] welche den Unterricht der Jugend in nützlichen Kenntnissen und Wissenschaften zur Absicht haben.' (Translated from the German by Ansgar Weymann.

7 The figures of this secondary school statistic comprise the so called Mittelschulen (middle schools - today ISCED Level 2 of secondary education). The figures for 117 respectively 129 public Gymnasium (grammar schools) and for private high schools have to be added.

8 This study combines a longitudinal analysis of administrative statistics and cluster analyses of provinces. It should be noted that 'terms like school, enrollment, brevet (certification that a teacher was qualified) could refer to quite different phenomena even at the same date and tend to change their meaning' in national and international comparisons (Grew \& 
Harrigan, 1991, p. 15). Furthermore, one could beg the question of whether figures are trustworthy or were produced for political, lobby and public campaign purposes.

9 Baker (2014) presents a very optimistic view on the schooled society and the ensuing educational transformation of global culture. A quiet educational revolution has generated an educated policy and an educated laity, he claims.

10 For further information see Pitts \& Kroncke 2014; for information about Great Britain see Graddy \& Pistaferri (2000); about Italy Mussida \& Picchio (2012).

11 The Frankfurter Zeitung was first established in 1856, and after the war 1949 it was re-established as Frankfurter Allgemeine Zeitung.

12 The Times did not have a front page in the usual sense until 1966. The first page of the paper previously contained advertising, family news, and the like. For the pre-1966 period, we have selected the first page of the home and foreign sections instead of the first page of the paper.

13 Depending on the accessibility of the particular newspaper's archive, the qualitative analysis ends in the years 2004 (New York Times), 2006 (Le Figaro), or 2007 (Frankfurter and Times). The quantitative analysis of all four newspapers ends in 2004.

14 There are no continuously published Sunday editions.

15 The 'Deutsch-Chinesische Hochschule' (German-Chinese University of Applied Sciences) opened October 25, 1909.

16 For more details on the human capital of nations, education and the growth of the economy see Hanushek and Woessmann, 2015.

17 The so called 'Bologna process' may be a good example of this phenomenon. 